Review

\title{
Energy Transition and Urban Planning for Local Development. A Critical Review of the Evolution of Integrated Spatial and Energy Planning
}

\author{
Paolo De Pascali * and Annamaria Bagaini \\ PDTA Department of Planning, Design and Technology of Architecture, Sapienza University, Via Flaminia 72, \\ 00196 Rome, Italy; annamaria.bagaini@uniroma1.it \\ * Correspondence: paolo.depascali@uniroma1.it; Tel.: +39-3483962856
}

Received: 26 November 2018; Accepted: 20 December 2018; Published: 23 December 2018

\begin{abstract}
The aim of the article is to analyse the evolution of spatial and energy planning integration, seen as a mean to foster local development, from the birth of the theme to the current prospects of shared sustainability and Decentralised Energy System (DES) solutions. The paper is a review of the evolution of the spatial and energy planning integration, exploring weaknesses and future opportunities. After an initial period of intense theoretical elaboration, the relationship between energy and city physical-functional organization and planning is still far from finding an implementation. The article explains this lack of integration through the analyses of significant steps in the last 50 years with the aim to outline current obstacles in achieving a more comprehensive vision of energy and spatial planning. The experiences selected highlight critical aspects concerning the trend towards the divergence of energy planning from systemic urban and spatial planning, also due to the low consideration of energy as a factor for local development. From the processes of decentralization and energy localism, some perspectives emerge which converge on the eco-energy district as a projection of the local energy community and which seem to enhance a more systemic and strategic dimension of planning.
\end{abstract}

Keywords: urban sustainability; energy planning; local development; sustainable energy action plan; energy community; energy district

\section{Introduction}

Since the 1970s researchers have studied the direct relationship between physical urban characteristics and energy systems, leading to an initial period of intense theoretical elaboration, from the end of the 1980s to the early 1990s [1-7]. The resulting systemic-critical framework of the relationship between energy and physical-functional organization has outlined the relevance of including energy-related planning and strategies in the spatial planning. Still now this theoretical awareness doesn't find an equivalent practical application in the day-life urban governance and management. It is generally accepted that in the sustainability global challenge, cities are the front-runners, with their strong role to be the core of the sustainable energy transition: role recognised by the high presence of energy efficiency themes on the European Urban Agenda [8]. However, a holistic or integrated approach comprehending energy efficiency/saving and urban planning is far from complete. A variety of strategies and approaches in this field are drawn up by different stakeholders at different levels, bringing to tackle separate key aspects, and hindering strategic energy efficiency planning [9]. Starting from this point, the paper examines the difficult evolution of the integration process between energy and spatial planning, through the results reached by some peculiar cases, reflecting on two different approaches: (1) Top-down and urban scale oriented (the Italian case 
of the energy and planning integration by law, and the ongoing development of the Sustainable Energy Action Plan); (2) and neighbourhood scale oriented urban projects (the experimentation of eco-districts and the new development of Energy Local Communities [10-13] and Energy District [14,15].

The novelty of this research approach concerns in displaying a comparison between different experiences, which refer to multiple categories of strategies and actions: Urban and Energy Plans-both Italian focused and European-, Urban Renewal Projects, Community based Energy Districts, along 50 years of research and practice.

Most other authors explain the weakness of the energy-related urban strategies, policies and action plans and the lack of energy-spatial planning integration by analysing single experiences. A comparing literature exists related to the Italian Urban Energy Planning [16], the PAES implementation assessment [17-21], the obstacles in energy planning at the urban scale [22], and the relevance of energy-spatial planning integration [23,24]. All these researches focus on one category of intervention, displaying weakness and possibilities for improvement. The particularity of this research is the will of outline the constant presence of barriers which affect different types of urban energy-oriented interventions.

After an initial literature review about the increase of energy topics' significance in the urban planning system, the paper runs through selected experiences with the aim to investigate the relationship between energy and spatial planning. The analysis starts with the study of five evolution steps of this integration path, with the aim of analysing and identify the strengths and weakness of this evolution process, in order to point out barriers of the integration, but also, to highlight opportunities for improvement. Is internationally recognised that the settlement model directly affects the urban energy consumption and, vice versa, the energy model shapes the physical and functional settlement organization, citizen behaviours, as well as the social inclusion process [5-7]. But the examples show how the energy-related policies and planning are still unintegrated with spatial planning and how it is seen as sectoral issues.

The work, starting from the evidence deduced from the literature and study cases, wants to suggest a potential integration strategy, represented by the Energy District and Energy Local Communities [12]. This direction opens to public and private initiatives for plants and grids linked to local socio-economic development, and it can add new strategic value to the spatial planning.

The experiences of Energy Districts and Energy Local Communities show a good opportunity to increase the integration grade between energy and spatial planning in order to face the current urban challenges.

\section{At the Beginning Was the Theory}

The attention to the urban and territorial aspects of energy emerges, at the international level, close to the first energy crisis in the early 1970s and it considers, from the beginning, the integration of energy variables in the urban planning as a crucial theme [3,5,6,25]. Between the 1920s and the 1940s, a few urban plans had considered the relationship between land use and energy consumption with the aim of reducing the direct energy costs, in order to achieve an economic growth (an example is the Tennessee Valley Authority project and other consumption reduction plans in the USA [26]). Burchell and Listokin [27] report a wide-ranging overview of the back in time literature, focusing mainly on land use and energy consumption. The study "The Cost of Sprawl" [25] represents the starting point of the energy/settlements theme for the diffusion reached internationally and the worldwide scientific debate generated. The research analyses the relationship between the city sprawl phenomena and the related energy costs (together with other parameters such as environment, management, investments, analysed from the cost side). It analyses different models and configurations of housing density until to define the lower burden of compact settlements. This schematic approach reached a lot of interest but was also strongly criticized $[1,28]$. The density/energy consumption ratio has become a sort of mantra in thematic publications and has opened a wide field of study up to the present day, with many positions in favour of high density but also some criticisms $[2,29,30]$. 
Fairly good international success has been attained by the contemporary work of Knowles [3], which proceeds in another direction, towards designing the form of settlements in synergy with the natural contexts and the local climatic conditions, in order to reduce fossil energy use and improve living comfort. The study, therefore, tends to improve the quality of the built environment through a better integration with the environmental conditions, with the help of new technologies. Along with this line, the consideration of the economic value of energy decreases, and the energy component acquires importance in the design field with the canons of the vernacular style, still followed in these days [31]. The work of Knowles continues previous research lines on the harmony between settlements and local environment, but with more specialized connotations, such as the using of environmental physical and technical parameters opened by Olgyay [32], and the naturalistic design by McHarg [33]. In this research path, we may include the earlier studies by Martin and March [34] about energy parameterization of the form of urban blocks, especially with regard to the solar gain. This approach will open the way to bioclimatic studies and design in which the energy issue has been considered only for buildings, without considering other types of consumption (transport, services, production) or the added value connected to the behaviours and energy consumption changing, depending from city shape. In this regard it is important to underline that the studies of Oke [35-37] on the urban heat island, showed how the solar gain can produce discomfort in the city (especially in warm and temperate climates) and not only benefits and can thus increase energy consumption. This consideration has been long ignored in planning and has been re-evaluated only recently. The article by Rosenfeld et al. [38], focused on the "cool communities", measures the economic commitment to reduce the heat island of Los Angeles through a wide urban forestry program, being an important reference for the following period. The study evaluates the economic benefits of reducing energy consumption due to air conditioning and the effects on improving the health of citizens in the city. The Economic European Community (EEC) itself designed the REG-VALOREN programme [39], basing all strategies on the valorisation of endogenous energies as a driver for local planning.

An organic analysis of the relationships between energy and urban spatial planning was defined by Susan Owens [5] in a small book that would later become a milestone, still quoted in the literature. Owens elaborates the theory of the two-way relationships between energy and the "physical-functional" organization of the city and examines in deep the links, in a theoretical framework, between energy and spatial planning. She highlights the need for a systemic approach in the consideration of this link, because of the energy topic pervasiveness in human activities and in the physical organization of the territory. Is, in fact, reductive to think about energy only in terms of a sectoral issue without considering the transformation of places; the consumption of buildings as well as mobility and transport, the distribution of activities (centralization and dispersion), and the comfort conditions.

A holistic approach runs towards energy-efficient land-use or towards integrated energy planning considering the inter-scalar character of energy. Thus, emerges the idea that energy does not regard only with the consumption-side, but it is a means to pursue the best urban living conditions, land use, and environmental protection and valorisation. An important contribution to the theme of energy integration in spatial planning is given by the authors Newman and Kenworty [40-42], which reinterpret the energy integration concept from the transport and mobility side. The work, published in a trilogy since the late 1980s, is the result of years of research in which was developed the "car-oriented city" concept as the generator of urban sprawl and energy waste. Their graphs of the relationship between population density and per capita consumption of gasoline in cities are famous and have been reported in many publications despite the approximation and schematic nature that characterize them.

From the end of the 1980s to the early 1990s, the general conceptual framework of the importance of energy and spatial planning integration appears to be defined. Still missing is the emission factor and the local pollution, whose importance has grown since the 1992 Rio Conference (in particular 
with the Local Agenda 21), and the development of market liberalization, which was implemented in several European countries, at the end of the century.

These two factors-environmental component and market liberalization-gave a positive contribution in achieving a more integrated approach of urban and energy planning. The overall emerging frame represents a worthy theoretical framework of integration, but it does not affect the daily urban planning process. The raising of awareness of the interaction between urban features and energy system (consumption, supply, distribution grid) have increased the complexity of managing the urban changings and problems. But at the same time, the increased awareness opens to innovative approaches which, as shown in the next parts, evidence new opportunities for the integration. For a long time, until now, the energy planning is focused on the consumption-side-more or less linked with the urban form and geometry, especially related to building's passive solar gains. The consideration of the economic parameter related to energy-saving is gradually decreased, and only in few cases, energy assumes a role in terms of the local economy grow. With the progress of liberalization, however, even with long implementation times and several obstacles, the attention is finally shifting to the economic value of shared and decentralised production. It opens to models widespread in the territory, more linked to the local socio-economic development.

\section{An Extreme Case: Integration by Law}

Italian Law No. 10/1991 [43] took effect to facilitate the implementation of the 1988 National Energy Plan, introducing two new plans: The regional Energy Plan (PER) (at the regional administrative level) and The Urban Energy Plan (PEC) (at the municipal level). The National Energy Plan, after several ineffective attempts, was definitively abandoned, but the Law No. 10/1991 has remained in force and has shown great foresight in many of its provisions, related to energy decentralization. It should be noted that the law came from 15 years of activity and scientific researches of a national program on energy, called "Progetto Finalizzato Energia" (Energetic Targeted Project), which included the specific subproject "Energy and Territory" [44]. The main quality was the introduction of the two energetic plans, with specific aims and objectives. The Regional Plan has been configured as a strategic plan at the macro level, with limited territorial connotations. The Urban Energy Plan focused to the local Renewable Energy Sources (RES) production in the beginning phase, is, however, a new and original planning tool which shows a high level of potentiality for urban spatial and managing planning. The law has required the implementation of an Urban Energy Plan only for cities with more than 50,000 inhabitants and is still in force. The Urban Energy Plan should have been introduced within the main Urban Master Plan (Piano Regolatore Generale, PRG), allowing it to find in the second one its mandatory framework, according to the National Planning System. The main interesting element is the duty for local authorities to integrate the energy issue in the Principal Planning Instrument (PRG). This interesting element shows how the final object of the law was the ordinary planning tool and not the new Energy Plan. The law, correctly, had foreseen the integration between energy planning and urban spatial planning, avoiding the sectoral plan.

However, the ambiguity of the law, which mentions the two plans (the PRG and the Energy Plan) separately, had fostered an incorrect interpretation of the second one as independent one. This interpretation gave an advantage to the separation of responsibilities process between local authority departments, which are usually expressions of different political positions and powers. In this way, the Urban Master Plan remained under the responsibility of the Urban Planning Department and the Energy Plan remained a duty of the Environmental Department, with a different political tie. This brought to a lack of coordination, with different (and sometimes conflictual) strategies set out by the two plans. In also the lack of penalties, brought Local Authorities to underestimate the importance to face the energy issue as a crucial key for their cities. The consequence was the downfall of the Energy Plan, the weaker of the two, which lost its potential effectiveness. Thus, the energy plan has often become a tool of political marketing, without any concrete implementation. There are no accurate data about the 114 local authorities under the duty to implement the Urban Energy Plan [16-45], 
and accounting for $36 \%$ of all Italian citizens. The Italian National Institute of Statistics (ISTAT) [46] shows that only the $38 \%$ of them have adopted the Energy Plan, of which the greater part is in the north of Italy (Table 1). But frequently the Energy Plans adopted are now old and without integration or connection with the ordinary planning instruments (Urban Master Plan, Mobility Plan, Building code, etc.). The Urban Energy Plan, according to the law, had first the aim of developing the urban renewable energies production. But, considering only renewable energies without developing the wide framework of the energy system makes it less efficient and effective. In a new step of upgrading, the plan became an Energy and Environmental Plan, working both in the energy field and related environmental impacts. The most interesting experiences are located in the Emilia Romagna region, a region with a long tradition of innovation in urban planning theory and characterized by good coordination between public departments. Here is possible to find some good experiences with the aim of integrating energy into spatial planning, such as the Urban Energy Plan (PEC) of Bologna [47]. It aimed to integrate the energy issue in the Municipal Master Plan (called Piano Strutturale Comunale, PSC), which is equivalent to the PRG. The principal element of this integration is represented by drawing "energy basins" (Bacini Energetici Urbani, BEU), which identify specific urban zones with a transformation destiny according to the PSC strategies [16]. These areas presented some convenience relationship to the energy issues. The experience raises three considerations. The first is the lack of a two-way influence between energy factors and urban transformation strategies. The Urban Energy Plan, in fact, does not seem to affect the localization of the zones, their dimensions, their functionalities or morphologies. The second is that the Energy Plan seems to be a sum of projects. The energy strategy does not affect the city as a whole, but it focuses only on small preselected areas. The town's energy future has not been affected, and the relationship between urban parts is not considered. The third is that 11 of the 14 BEUs are urban new-development areas. In this way, the new energy-oriented planning approach is related only to new buildings and new neighbourhoods. "Built areas" are not considered.

Another example is the PRODEM (PROgetto Dell'Energia Modenese-Modena's Energy Project) [48]. It proposes a new integrated approach but still with some blurry methodologies in linking physical and energy-saving strategies and RES production policies. The Plan divides the whole territory into different Territorial Energy Basins (Bacini Energetici Territoriali, BET) based on their particularities. On them, the Plan develops strategies, linked to the large-scale plan, named Modena's PTCP (Territorial Coordination Plan) [49].

The Urban Energy Plan, as defined by the law, has been not abrogated, and the law is still in force. But the production of these type of plans is decreasing. Likewise, the best practices, adopted in the Emilia Romagna region, have been left out. The integration suggested by the law did not work or even it was never built up.

Since 2012 there has been no more information about these plans. No municipality had upgraded its Urban Energy Plan or monitored its achievements. The Covenant of Mayors (CoM) initiative and the Sustainable Energy Action Plan (SEAP) [50] have replaced the national one, due for European funds and investments connected with the signature. Most of the Municipalities under the duty to implement an Urban Energy Plans have simply shifted to the new PEAS format, forgetting the old one. This shifting was in many cases only formal, when the strategies and actions involved in the national plan were reintroduced in the implementation of the new SEAP. In 2018 in Italy there are more than $4000 \mathrm{CoM}$ signatories and more than 3000 SEAP submitted [17] (Figure 1). The SEAP is now considered the unique tool to manage and act on the Urban Energy field.

The low local authorities' technical knowledge and expertise was the main cause of the Urban Energy Plan failure, with the lack of operativity of the institutional framework. Furthermore, the law and related Plans gave little attention to the economic value of energy. Only in the design of the basin is recognised some general considerations of the optimization of high consumption areas in relation with economically profitable shared energy production plants. 
Table 1. Overview of Italian cities with an Urban Energy Plan and the shifting to the Sustainable Energy Action Plan.

\begin{tabular}{|c|c|c|c|c|c|c|c|c|c|c|c|}
\hline & $\begin{array}{c}\text { Main Cities } \\
\text { (Capoluoghi di } \\
\text { Provincia) }\end{array}$ & $\begin{array}{c}\text { n. of } \\
\text { Municipalities } \\
\text { with a PEC (2010) }\end{array}$ & $\begin{array}{c}\text { n. of CoM } \\
\text { signatories } \\
\text { (2015) }\end{array}$ & $\begin{array}{c}\text { Year of PAES } \\
\text { Submission } \\
\text { (2015) }\end{array}$ & $\begin{array}{l}\text { Signatories with } \\
\text { Submitted } \\
\text { Monitoring (2015) }\end{array}$ & & $\begin{array}{c}\text { Main Cities } \\
\text { (Capoluoghi di } \\
\text { Provincia) }\end{array}$ & $\begin{array}{c}\text { n. of } \\
\text { Municipalities } \\
\text { with a PEC (2010) }\end{array}$ & $\begin{array}{c}\text { n. of CoM } \\
\text { Signatories } \\
\text { (2015) }\end{array}$ & $\begin{array}{c}\text { Year of PAES } \\
\text { Submission } \\
(2015)\end{array}$ & $\begin{array}{c}\text { Signatories with } \\
\text { Submitted } \\
\text { Monitoring (2015) }\end{array}$ \\
\hline 1 & Torino & $\mathrm{x}$ & $x$ & 2010 & $x$ & 59 & Terni & - & - & - & - \\
\hline 2 & Vercelli & - & $x$ & - & - & 60 & Pesaro & $\mathrm{x}$ & $x$ & 2012 & $x$ \\
\hline 3 & Novara & - & $x$ & 2013 & - & 61 & Ancona & - & $x$ & 2013 & - \\
\hline 4 & Biella $(b)$ & $\mathrm{x}$ & - & - & - & 62 & Macerata (b) & $\mathrm{x}$ & $x$ & 2013 & - \\
\hline 5 & Cuneo & $\mathrm{x}$ & $x$ & - & - & 63 & Fermo & - & $x$ & 2013 & - \\
\hline 6 & Verbania & - & $x$ & 2015 & - & 64 & Ascoli Piceno & - & $x$ & 2013 & - \\
\hline 7 & Asti & $\mathrm{x}$ & $x$ & - & - & 65 & Viterbo (c) & - & $x$ & - & - \\
\hline 8 & Alessandria & - & $\mathrm{x}$ & 2010 & - & 66 & Rieti (c) & - & $x$ & - & - \\
\hline 9 & Aosta & - & - & - & - & 67 & Roma & $\mathrm{x}$ & $x$ & 2013 & - \\
\hline 10 & Imperia & - & - & - & - & 68 & Latina & - & $x$ & 2014 & - \\
\hline 11 & Savona & - & $x$ & 2014 & - & 69 & Frosinone (c) & - & $x$ & - & - \\
\hline 12 & Genova & $\mathrm{x}$ & $x$ & 2010 & $x$ & 70 & L'Aquila & - & $x$ & 2012 & $x$ \\
\hline 13 & La Spezia & - & $\mathrm{x}$ & 2012 & - & 71 & Teramo & $\mathrm{x}$ & $x$ & 2012 & - \\
\hline 14 & Varese & - & - & - & - & 72 & Pescara & - & $x$ & 2012 & $x$ \\
\hline 15 & Como (c) & $\mathrm{x}$ & $x$ & - & - & 73 & Chieti & - & $x$ & 2012 & $x$ \\
\hline 16 & Lecco (b) & $\mathrm{x}$ & - & - & - & 74 & Isernia & - & $x$ & 2011 & - \\
\hline 17 & Sondrio & - & - & - & - & 75 & Campobasso & - & $x$ & 2013 & - \\
\hline 18 & Milano & $\mathrm{x}$ & $x$ & - & - & 76 & Caserta & - & - & - & - \\
\hline 19 & Monza & $\mathrm{x}$ & $\mathrm{x}$ & 2014 & $x$ & 77 & Benevento (c) & $x$ & $x$ & - & - \\
\hline 20 & Bergamo & $\mathrm{x}$ & $x$ & 2011 & $x$ & 78 & Napoli & - & $x$ & 2012 & - \\
\hline 21 & Brescia & $\mathrm{x}$ & - & - & - & 79 & Avellino & $\mathrm{x}$ & $x$ & - & - \\
\hline 22 & Pavia & - & $x$ & 2013 & - & 80 & Salerno & - & $x$ & 2013 & $x$ \\
\hline 23 & Lodi & - & $x$ & 2011 & $x$ & 81 & Foggia & $\mathrm{x}$ & - & - & - \\
\hline 24 & Cremona & $\mathrm{x}$ & $x$ & 2013 & - & 82 & Andria & - & $x$ & 2013 & - \\
\hline 25 & Mantova & - & $\mathrm{x}$ & 2014 & - & 83 & Barletta & - & $x$ & 2013 & - \\
\hline 26 & Bolzano & - & $x$ & 2014 & - & 84 & Trani & - & $x$ & 2013 & - \\
\hline 27 & Trento & $\mathrm{x}$ & $x$ & 2015 & - & 85 & Bari & $\mathrm{x}$ & $x$ & 2011 & - \\
\hline 28 & Verona & - & $x$ & 2012 & $x$ & 86 & Taranto & - & - & - & - \\
\hline 29 & Vicenza & - & $x$ & 2013 & $x$ & 87 & Brindisi & - & $x$ & 2014 & - \\
\hline 30 & Belluno & - & $x$ & 2015 & - & 88 & Lecce & - & $x$ & 2015 & - \\
\hline 31 & Treviso & - & $x$ & 2012 & $x$ & 89 & Potenza & $\mathrm{x}$ & $x$ & 2012 & $x$ \\
\hline 32 & Venezia & $\mathrm{x}$ & $x$ & 2012 & $x$ & 90 & Matera & - & $x$ & 2015 & - \\
\hline 33 & Padova & $\mathrm{x}$ & $x$ & 2011 & $x$ & 91 & Cosenza & - & $\mathrm{x}$ & 2013 & - \\
\hline 34 & Rovigo & - & - & - & - & 92 & Crotone & - & - & - & - \\
\hline 35 & Pordenone & - & $x$ & - & - & 93 & Catanzaro & - & - & - & - \\
\hline 36 & Udine & $\mathrm{x}$ & $x$ & 2010 & $x$ & 94 & Vibo Valentia & - & - & - & - \\
\hline 37 & Gorizia (b) & $\mathrm{x}$ & $x$ & 2015 & - & 95 & Reggio di Calabria & - & - & - & - \\
\hline 38 & Trieste & - & $x$ & 2014 & $x$ & 96 & Trapani & - & - & - & - \\
\hline 39 & Piacenza & $\mathrm{x}$ & $x$ & 2011 & $x$ & 97 & Palermo & $\mathrm{x}$ & $x$ & 2015 & - \\
\hline 40 & Parma & $\mathrm{x}$ & $x$ & 2014 & - & 98 & Messina & - & $\mathrm{x}$ & 2015 & - \\
\hline 41 & Reggio nell'Emilia & $\mathrm{x}$ & $x$ & 2011 & $x$ & 99 & Agrigento (c) & - & $\mathrm{x}$ & - & - \\
\hline 42 & Modena & $\mathrm{x}$ & $x$ & 2011 & - & 100 & Caltanissetta (c) & - & $x$ & - & - \\
\hline 43 & Bologna & $\mathrm{x}$ & $x$ & 2012 & $x$ & 101 & Enna & - & $x$ & - & - \\
\hline 44 & Ferrara (d) & $\mathrm{x}$ & $x$ & 2013 & - & 102 & Catania & $\mathrm{x}$ & $\mathrm{x}$ & 2015 & - \\
\hline 45 & Ravenna & $\mathrm{x}$ & $x$ & 2012 & $x$ & 103 & Ragusa & - & $x$ & 2015 & - \\
\hline
\end{tabular}


Table 1. Cont.

\begin{tabular}{|c|c|c|c|c|c|c|c|c|c|c|c|}
\hline & $\begin{array}{c}\text { Main Cities } \\
\text { (Capoluoghi di } \\
\text { Provincia) }\end{array}$ & $\begin{array}{c}\text { n. of } \\
\text { Municipalities } \\
\text { with a PEC (2010) }\end{array}$ & $\begin{array}{l}\text { n. of CoM } \\
\text { signatories } \\
\text { (2015) }\end{array}$ & $\begin{array}{c}\text { Year of PAES } \\
\text { Submission } \\
\text { (2015) }\end{array}$ & $\begin{array}{c}\text { Signatories with } \\
\text { Submitted } \\
\text { Monitoring (2015) }\end{array}$ & & $\begin{array}{c}\text { Main Cities } \\
\text { (Capoluoghi di } \\
\text { Provincia) }\end{array}$ & $\begin{array}{c}\text { n. of } \\
\text { Municipalities } \\
\text { with a PEC (2010) }\end{array}$ & $\begin{array}{c}\text { n. of CoM } \\
\text { Signatories } \\
\text { (2015) }\end{array}$ & $\begin{array}{l}\text { Year of PAES } \\
\text { Submission } \\
\text { (2015) }\end{array}$ & $\begin{array}{c}\text { Signatories with } \\
\text { Submitted } \\
\text { Monitoring (2015) }\end{array}$ \\
\hline 46 & Forli' & $\mathrm{x}$ & $x$ & 2011 & $x$ & 104 & Siracusa & - & - & - & - \\
\hline 47 & Rimini & $\mathrm{x}$ & $x$ & 2014 & - & 105 & Sassari & $\mathrm{x}$ & $x$ & 2013 & - \\
\hline 48 & Massa & $\mathrm{x}$ & $\mathrm{x}$ & - & - & 106 & Nuoro & - & $x$ & 2012 & - \\
\hline 49 & Lucca & - & $x$ & 2013 & - & 107 & Oristano & - & $x$ & 2013 & - \\
\hline 50 & Pistoia & - & - & - & - & 108 & Cagliari & - & $x$ & 2014 & - \\
\hline 51 & Firenze & $\mathrm{x}$ & $x$ & 2011 & - & 109 & Olbia & - & $x$ & 2013 & $x$ \\
\hline 52 & Prato & - & $x$ & 2015 & - & 110 & Pausania & - & $x$ & 2013 & $x$ \\
\hline 53 & Livorno & $\mathrm{x}$ & $x$ & 2014 & - & 111 & Lanusei & - & $x$ & 2015 & - \\
\hline 54 & Pisa & - & $x$ & 2012 & $x$ & 112 & Tortolì & - & $x$ & 2015 & - \\
\hline 55 & Arezzo (c) & - & $x$ & - & - & 113 & Sanluri & - & $x$ & 2015 & - \\
\hline 56 & Siena & $\mathrm{x}$ & $x$ & - & - & 114 & Villacidro & - & $\mathrm{x}$ & 2014 & - \\
\hline 57 & Grosseto & - & $x$ & 2015 & - & 115 & Carbonia & $\mathrm{x}$ & - & - & - \\
\hline \multirow[t]{2}{*}{58} & Perugia & $\mathrm{x}$ & - & - & - & 116 & Iglesias & - & $x$ & - & - \\
\hline & & & & & & & $\begin{array}{c}\text { Italy (116 capital } \\
\text { cities) }\end{array}$ & 44 & 95 & $\begin{array}{l}\text { Average year } \\
2013\end{array}$ & 26 \\
\hline
\end{tabular}

Source: Istat. (a) The law 10/91 required the implementation of an Urban Energy Plan (PEC) only for cities with more than 50,000 inhabitants. (b) Municipalities without the duty of the Urban Energy Plan (PEC) implementation, with less than 50,000 inhabitants. (c) Municipalities without a submitted PAES after one year of CoM signature. (d) Joint PAES (Ferrara, Masi Torello, Voghera). 
Number of signatories

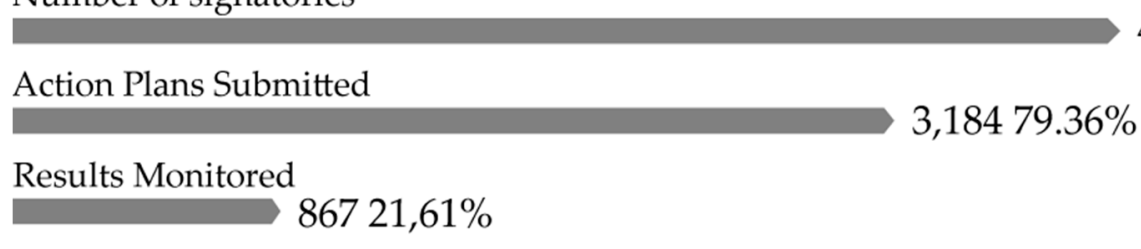

\section{$4,012100 \%$}

Figure 1. Overview of CoM signatories and SEAP submitted in Italy.

Finally, one of the causes of the failure is due to the substantial top-down approach that characterizes these plans, aimed to protect the environment and not oriented to the socio-economic value development. However, significant experiences remain for the attempt to integrate energy into spatial planning. It is also important to highlight the emergence of the low political appeal of long-term initiatives, which do not bring immediate results, such as energy interventions linked to deep urban transformations. The strategic planning loses its role in favour of small actions with fast results and huge advertising effects. This tendency is increasing the attraction of an Urban Planning model based on sectoral actions and visions.

\section{The Sustainable Energy Action Plan and the Discreet Charm of the Sectorial Vision}

Within different initiatives involved in the urban energy field, the Covenant of Mayors (CoM) today engages almost 8000 cities in Europe [17]. The CoM is a bottom-up movement launched by the European Commission, and it aims to directly involve local authorities, by a voluntary agreement, in developing and implementing the Sustainable Energy Action Plan (SEAP), by which they commit to reducing emissions by at least $20 \%$ by 2020 , through energy efficiency and renewable energy actions [51]. It represents an innovation in the European energy-saving policies framework, in which the main innovation is a strong relationship and linking between strategies and territorial context and needs. The CoM has been recently defined as "the world's biggest urban climate and energy initiative" [52]. But the success of this initiative and its evolution: The Sustainable Energy and Climate Action Plan (SECAP), do not remove the complexity and problems recognised in the SEAP implementation and effectiveness [53]. The huge success and share of the initiative, not only in Europe, brought many researchers to analyse this experience in different contexts, looking for strengths and weaknesses. Christofordis et al. [18] focused their research on the SEAP implementation barriers and on the consequences for citizens' life in Greece. Bulkeley and Castán Broto [54], through a scoping study, have analysed 627 urban climate change experiments in 100 global cities, among to the CoM initiative, with the aim to understand the consequences of these initiatives on the policy-making process. Rivas et al. [19] in a Joint Research Centre (JRC) final report, have carried out an in-depth analysis of selected SEAPs, based on a sample of 25 cities in Europe. The study sought to identify common characteristics of this instrument, giving a picture of the strengths and weaknesses of different cities in their attempts to reduce their total GHG emissions by 2020.

As demonstrated by many studies the high number of signatories and the importance achieve by the SEAP do not necessarily imply that the goals of CoM initiative will be achieved [18]. The aim of this part, through a literature review and the analysis of some experiences carried on by Italian municipalities in the term of SEAPs' development, is to achieve a clearer comprehension of the difficulties observed in the urban energy transition process, trying to understand the integration level reached between energy and spatial planning. Regarding the SEAP, the more relevant and innovative aspects of the initiative are the standardized format; the Baseline Emission Inventory (BEI)—which gives a concrete base to the Plan-; the three levels of intervention: (1) energy conservation, (2) energy efficiency, and (3) use of renewable sources [50]; the two timelines of strategies (short- and long-term); and the capacity to engage small towns, which represent $88 \%$ of all cities involved [20]. The SEAP, due to its characteristics, would have the opportunity to concretely affect the local level energy model if linked to the spatial planning, which represents a realistic way to put in practice the SEAP's 
strategies and actions [53]. The SEAP, in fact, do not operate at the level of the building but rather at the level of the whole city involved (municipality or region) [55]. It works for the sustainable development of a territory or city, in terms of environmental protection, social and behaviour change, economic development. Nonetheless, some negative elements emerge from this initiative, especially concerning the way in which local authorities manage energy issues and Urban Energy Plans in general. Local Authorities still have a scarce comprehension of the complexity related to this field and its cross-sectorial characteristic. For a long time, many authors [6,56,57] and international reports [58] have considered spatial planning as a key element in tackling the causes and consequences of energy consumption and climate change. However, the translation of energy-climate-related policies into ordinary planning instruments seems to be still inefficient [59]. Even if the complexity of the urban system and the impossibility of solving it through sectorial strategies is internationally recognized [60], is shared a thinking about energy as a mono-disciplinary or technological issue [45]. The main two critical elements which emerge from the implementation of the SEAP are the mono-disciplinary and sectoral-based vision, and the sustainability marketing. Analysing some Italian experiences of SEAPs is possible to observe the same lack of integration and correlation between Energy related planning and the urban spatial planning instruments (such as the city master plan, the urban mobility plan and so on). A cross-level evidence of this sectorial tendency is expressed by the inclusion, in the SEAP's format, of categories such as urban planning, land use, public procurement, working with citizens, water and waste management, urban regeneration, urban agriculture in the sub-sector "Other". A local authority may choose to orient its energy and emission-reduction strategies towards different suggested sub-sectors without being obliged to consider all of them. Rivas et al. [19] show that more than the $50 \%$ of the 25 samples analysed in their research did not include actions in the sector "others".

In general, the aggregation of categories, which strictly influence the energy consumption model, within optional sub-sectors, shows a failure to acknowledge the cross-sectoral and key relevance of energy issues. It fosters the shared seeing of energy as a final use and not as a derived component, which is affected by the urban form, structure, organization, management, and synergy of urban elements and systems. The three main sectors, considered by the SEAP format (building, transport, and energy production and supply) are effectively the most energy-intensive sectors, but they are also an expression of the urban form and governance. Therefore, it is important to consider the straight relation between energy and urban components in order to allow and reach a long-term urban energy transition and a higher level of sustainability. The JRC report [20] shows that at the category "Other" is ascribed high potential in reducing GHG emissions (13\%) and high potential for energy savings $(15 \%)$, but it is not possible to understand the effective role of each component or how much local authorities give importance to the energy-spatial planning integration. Through literature review and Italian SEAPs analysis is possible to observe a shared tendency in operating on similar actions with less effect on urban and spatial planning decisions. Crocci et al. [21] show, from a comparative analysis of 124 European SEAPs, that the main sustainability drivers are related to sectorial aspects (such as incentives for purchasing efficient vehicles, the promotion of new technology for private energy production (photovoltaic panels), the promotion of CHP systems), or to consolidated strategies, such as efficient building standards. Few reduction ambitions (GHG emissions reduction, energy saving) are set out with regard to spatial planning regulation, land-use management, waste management, behaviour changes, or smart grid development. Those are structural elements which affect the way in which the city is regulated, built, and managed. But also, they bring to results less immediately perceived. However, keep promoting the same strategies may not bring to the desired results. Sectoral strategies may be even hindered if they are not integrated into ordinary urban policies and planning instruments. The analysis of urban climate change experiments carried out by Bulkeley and Castán Broto [54] showed that the experiments in Europe were predominantly conducted in the fields of the built environment, urban infrastructure (energy, waste, water) and transports, whereas urban form/planning, adaptation to climate change and carbon sequestration played only a minor role accounting for less than $25 \%$ of the experiments. The urban master plans and urban policies should, 
instead, internalize and foster the energy transition to a low-carbon urban system, making the energy issue relevant to daily life [50]. Sometimes cities are under different levels of regulation, plans, and policies in terms of urban energy management. For example, in Italy, which represents $57 \%$ of CoM signatories, the energy-related features are controlled by different instruments, as presented in the preview parts (Town Energy Plan, Regional Energy Plan, National Energy Strategy). Without a coordination, the effectiveness of the SEAP can be reduced, bringing to a conflict status between strategies and policies. SEAP should not be just another nice document, but part of the corporate culture [20], and an opportunity to transform cities into "living-labs" [56]. This idea brings to the second main problem token off by this analysis: the marketing charm of the SEAPs implementation.

Planning, implementation, and monitoring are the three main phases by which SEAP goals can be achieved [53]. The SEAP monitoring phase permits to evaluate strategies and actions in a continuous improvement and revision process. It is a core stone of the SEAP implementation, starting from the second year of the action plan. But the few monitoring reports sent by signatories, show a small understanding of the importance of the tool and its common use as an "eco" marketing instrument. For example, in Italy only the $21.61 \%$ of the total signatories (4000 municipalities in January 2018), have started the monitoring phase, submitting the first report to the CoM organization, while the $17 \%$ of the Italian SEAPs have been suspended due to the lack of municipalities profitable involvement (Figure 1). This is not only an Italian problem or difficulty. Rivas et al. [19] have noticed a shared failure by local authorities in the monitoring phase of their SEAPs.

These data are connected to some shared problems, such as the limited capacity building of the local authorities, the lack of financial resources-which discourages the development of local measures in terms of capital subsidies and grants [16] - the marketing vision of the SEAP, and finally the still limited interest in land-use-based mechanisms to govern energy as an urban issue. A barrier to this integration could be attributed to the difficulty of coordination between local public departments, which leads to a permanent conflict between responsibilities and powers (environmental protection, land-use, and spatial planning, economic and social affairs, building and infrastructure management, mobility and transport, budget and finance, procurement, etc.).

Non-holistic, sector-oriented policies and administrative practices might lead to wrong steering from an overall perspective [23]. Improving the collaboration and coordination between various departments in the local administration is essential for integrating energy-related strategies into each process, policy, and action carried out by the local authority. Another limit could be seen in the form of the so-called NIMTO phenomena ("not in my terms of office"), which refers to a fear, or public incapacity, to face with the complexity and uncertainty of urban, energetic, and climate problems. All of these could get worse if connected with an idea of sustainability such as a means of marketing to attract financial investments or to promote political power. Christoforidis et al. [18] have noticed that many mayors did not have a clear picture of what COM is and of the obligations that it is imposing to the local communities, seeing the initiative as a good means for the municipal advertising. Additionally, another problem could be seen in the lack of spatial dimension of energy data, seen by Rivas et al. [19] as the main weakness lay in how the plans were implemented and monitored. These aspects need to be improved. Some supporting planning tools are developing to help local authorities to take better decisions in the energy-related policies. Planning tools, such as urban energy mapping, can support integrated spatial and energy planning, in the way in which they show the direct spatial correlation between energy and urban elements (density, urban form, land use, functional mix, mobility, local energy resources, energy grids etc.). They may create a basic understanding of the system interrelations, helping to create a common vision and common objectives between interests and stakeholders, leading to more sustainable decisions and cross-sectoral strategic actions. The lack of a territorial visualization of the urban energy consumption and production could be at the base of the standardization of energy-efficiency strategies and their low-level integration with spatial planning. Researches on urban energy planning [23] and "exergy cascade" [61,62] show the relevance of basing the decision-making process on energy mapping or other visualization tools. 
In conclusion, what is emerging from this analysis is the general absence of a strategic dimension in the urban planning system in favour of sectorial actions with a short-term vision which can give fast results. This tendency is becoming a general methodology of the urban governance process. Instead, energy should be a key issue in every urban decision to produce concrete and effective results. All these problematics hinder the vision of the SEAP as a way of developing local sustainable measures that would enable cities to achieve better urban planning and socioeconomic development [19]. In this sense is evident the huge lack of the industrial and economic sector in the strategies developed by SEAPs. For the industry one, the reason is related to the presence of the European Emissions Trading System (ETS), which already controls the industrial GHG emission and fixes the sector benchmarks. This absence in the BEI and in the SEAPs does not allow a holistic approach, especially related with the unconventional RES presence in the local context-such as the excess of heat from the industrial processes-and with the previously quoted theory of "exergy approach". The low-exergy (low-ex) principle strives for limiting exergy losses in and between process steps by inserting as many function steps in an energy chain as possible, as in a cascade, from industrial production to room heating, with low-quality energy demand [61]. Not considering the industrial production inside the strategies of energy-saving and energy-efficiency, in one hand does not permit to understand the energy chain and the relation between local energy production and consume, and in the other hand it confirms a shared vision of the energy policies directed only to the GHG reduction, disconnected to the whole urban economic development. The energy issue, linked to RES production and supply, may become in the next years one of the main economic sectors within cities, with high income and returns. The European STRATEGO project [63] aims to show to the local and national authorities the incredible energy potential already available in their territories. The project had the objective to implement more efficient heating and cooling solutions, by an interactive map (The Pan-European Thermal Atlas) which shows the local RES potential (solar thermal, geothermal, relative accessibility of biomass, waste heat resources from industries and agriculture or other urban functions) in relation with the urban thermal demand. In the developing of a SEAP is important to take in consideration also these information and opportunities to build up strategies towards an urban energy-turn.

\section{Energy without Development: Eco-Living in the Fragmented City}

In the fragmented contemporary city, emerged from the urbanization processes in the last century, we can clearly recognize the different neighbourhoods' development patterns that have played an important role in pushing the fragmentation itself. The role of the neighbourhood as a minimal unit of intervention in the urban expansion has been developed starting from the early twentieth century in Europe. The applications of Clarence Perry's schemes of the Neighbourhood Unit [64], the experiences of the Modern Movement, the huge social housing projects in the second part of the century as well as the speculative private initiatives, have changed the shape, the geometry and the social interaction of our cities. We focus on two attributes that characterize the twentieth-century district, and still presented in the current urban regeneration projects, especially regarding the several eco-district experiences: (1) The Community/identity production and (2) The Self-sufficiency achievement.

(1) Particular attention has been dedicated during the second half of the twentieth century to the creation, with a top-down approach, of the sense of community and the belonging to the site. In other words, how the design can favour the formation of a feeling of community/identity in the inhabitants and how spatial configurations can be used for this purpose. Two main lines of application emerge: on the one hand the realization of spaces for collective use and hierarchical sets de grandeur conforme [65] (neighbouring units, unité d'habitation, functional neighbourhood); and on the other, the search for an emotional link based on the construction of an "affective ties", a spatial projections of cultural-historical characteristics, often presumed, and hard to maintain or create (working-class neighbourhood, rural village, etc.). But reaching a sense of community or identity, according to the two directions and through the design, has been difficult or impossible, especially among inhabitants with different origins and socio-economic 
situations. The emphasis on functionalist canons for high-density districts, the imposition of social spaces, and the aggregation of inhabitants with socio-economic problems have favoured in many cases illegal activities, decay, and social conflicts, which have later imposed heavy regeneration interventions in some of these neighbourhoods—-for example Bijlmermeer in Amsterdam [66] and Le Vele in Naples [67].

(2) The projects of new urban districts were also based on the concept of self-sufficiency, both for public initiatives then private ones, in which self-sufficiency (especially related to services, energy, food, water resources etc.) became an element of real estate marketing, to sell a "qualitatively different" product. The self-sufficiency (real or perceived, often realized later or not reached at all, but only "sold") become also a driver to build up the sense of community. The self-sufficiency concept leads to a further separation of the newly transformed parts from the whole urban context, towards a city composed of distinct and closed parts (also with fences). We are speaking about districts with a strong share social base and with clear morphological characteristics, tending towards intentional segregation or self-segregation.

The characteristics of identity-based and self-sufficiency districts are still present, in different ways, in the concept behind the eco-district experiences or eco-neighbourhood experiences. In the literature, around 20 eco-districts in Europe are several times quoted and described. They represent a reference followed by several urban projects that are still not so numerous, perhaps 1000 projects [68]. Generally, eco-districts were created with the aim of a participatory governance in which energy autonomy and ecological objectives took a central role. But the self-sufficiency is also followed for the water cycle, waste recycling, food production, and even alternative mobility systems and urban comfort conditions. All urban interventions, that can be linked directly or indirectly to the eco-energy component, became pervasive even in cultural terms. The "marketing" related to these examples has been incredibly huge, instead of the verified eco-friendly results achieved. There are few studies that prove the efficiency reached by the eco-districts, in terms of energy-saving and environmental protection. The urban eco-housing has to been considered as a more complex condition than a simple living in high performed buildings; especially for the most receptive social categories (intellectual, middle-class, politically progressive), and it tends to assume an overall dimension that pervades human behaviour and relationships.

The eco-districts became the representation of an ideological space, as well as a physical space able to translate the first in a physical dimension, where living and cohabiting converge. Living in an eco-district meant to stand out from the rest of the citizens, in a healthier and environmental respectful urban contest. The shared identity is present before deciding to live in an eco-district (the same for the cohousing initiatives). Some exceptions exist, such as the Social-Housing district with an ecologic aim (the Zaragoza eco-district for example) in which the housing assignment derived from a waiting list. In general, living in an eco-district is the result of a private choice derived from an individual socio-economic framework. In the twentieth century's neighbourhoods, this was not possible for the social housing initiatives, where the assignment of housing was based on ranking: was not allowed deciding with whom cohabit. In the eco-district the characteristics of self-sufficiency and separation remain, aiming to divide rather than to integrate the communities and the urban patterns. These districts are imagined as islands of well-being in the chaotic and polluted urban context. A kind of incomplete small urban utopias in the global city-world, especially under economic terms. The risk of a self-segregation emerges, perhaps more intense than in the twentieth-century neighbourhoods. The tendency is to mark the separation from the rest of the city, almost a self-confinement, towards the establishment of elite closed communities, based on a voluntary process. In the eco-districts, the energy component is integrated into the project and it can contribute in creating a sense of community, but it does not seem to help the urban integration. In the eco-districts, the energy component assumes a central and dominant role for the quality of living within a common ideological base of self-sufficiency. The economic value of energy, as a mean of development, is not considered and there are no opportunities for a systemic integration between the different urban patterns, given only 
by a more holistic energy planning or urban strategy. The eco-district concept increases the number of monofunctional districts and the urban fragmentation. The theme of sustainable development is not taking in account, or maybe it has only a marginal role, alongside the theme of the eco-living. The relationship between energy and economic development is not considered. But it has to be involved in another scale of the urban decision-making process for achieving a long-term effect.

\section{Discussion}

The two-level of investigation (urban scale and neighbourhood scale) outline some shared problems, useful to understand the current level of energy and spatial planning integration. It's clear that there is a deep gap between theoretical efforts and practical implementation. From literature is acknowledged the direct and mutual relationship of energy and urban spatial dimension. Some authors consider spatial planning as a mean to face climate change and energy saving challenges $[5,6,16,23,56,57,60-62]$. As in a cascade, the effects of spatial planning are spread from one level to another, from one urban factor to another one. This centrality leads urban design to have a high impact on energy consumption, influencing the design of buildings, urban geometry, land use, mobility systems, energy distribution systems and people behaviours [7]. But this increasing awareness doesn't influence urban strategies, policies, and actions. The examples exanimated show how the energy-related policies and planning are unintegrated with spatial planning. The different initiatives energy-oriented weakly affect economic, social, and spatial aspects of urban development and transformation. These experiences display multiple ways to deal with energy in urban strategies and actions. The eco-districts example (Section 5) shows a vision of the Energy topic as a shared identity for closed communities. The lack of effectiveness of several energy plans and policies (the PAES initiatives, for example in Section 4) points out a vision of the Energy topic as a marketing solution. Lastly, the mandatory top-down imposition of the Urban Energy Plan (Section 3) shows the increasing of a sectoral approach related to energy planning. But to achieve a more sustainable urban development, the energy transition process should be a permeating strategy, especially within the urban planning policies and dimensions: Normative-Strategic-Spatial, which should assume and internalize the energy system as a crucial chain to meet national and global low-carbon ambitions.

The current energy policies are far to find a space in the urban decision-making process. They deal with a single aspect case-by-case, often with a building-scale focus, considered as an entity independent of its context [7]. In the best cases, the Urban Energy Planning focuses on the mobility system, on local RES production or on energy distribution infrastructures. While spatial planning integration is not taken into account. Thus, Energy planning assumes a sectorial nature, with separated decision arenas and actors involved, due also for the lack of spatial dimension given to the energy issue. What emerges mainly from this comparative analysis is the presence of a constant underestimation of the energy topic relevance within the daily-life urban policymaking and spatial planning to achieve efficient results, able to face with climate change and urban challenges. The Italian case shows that the nature of the Plan is not the main reason for inefficiency or lack of integration. The Urban Energy Plan (law N. 10/91 [43]) lost gradually its importance in favour of the PAES one, starting from 2012. But the limits of the first are easily spotted out in the second one. Thus, it opens the possibility to highlight shared and structural problems, badly affecting the energy-urban turn. The insufficient integration between energy strategies and spatial planning largely affects the efficiency of results [16]. A first shared limit is the prevalence of a rhetorical dimension instead of a project-oriented vision. A second limit is the opposite one, the lack of a long-term and strategic vision. Another limit relates to the urban complexity and the uneasy understanding of the relationship between decision and unexpected impacts. The urban complexity doesn't help the Local authorities to understand easily the consequences of their decisions and actions, bringing them to act in a comfort zone [69]. A fourth limit is the preference of keeping adding policies and plans within an already overabundant normative system, without coherence and integration, instead of reforming the existed ones. The last problem relates to the "eco" marketing tendency, which brings to single demonstrative actions or projects, leaving the whole unchanged. 


\section{Energy District as a Driver for Local Development. Towards a Possible Integration?}

The DES (Decentralised Energy System) [12] may be a fertile operating solution for building inclusive communities and boosting urban regeneration. This solution involves the local valorisation of the economic component connected with the energy issue, so far limited by the predominance of the environmental-ecological component. The energy sector plays an important role in the European economy, showing also a progressive growth in the efficiency of the socio-economic system. In fact, despite the energy intensity of the European economy has been decreased considerably from $173 \mathrm{~kg}$ of oil equivalent for $€ 1000$ in 1995 to $119 \mathrm{~kg}$ in 2016 [70], the energy costs remain high with an increasing tendency. "Overall energy system costs increase from 11.2\% of EU GDP in 2015 to about $12.3 \%$ of EU GDP by 2020, also driven by projected rising fossil fuel prices. They stabilise at such levels until 2030, and decrease thereafter, reaping the benefits of the investments made" [71].

Considering a value of EU GDP close to $€ 15,000$ billion [72] (at current market price), the value of energy costs is approximately around $€ 1800$ billion, stable until 2030 and in decreasing by few points per year till 2050 but in a growing trend as absolute value, according with the GDP growth. This is an important economic value for a market controlled by large energy industries and utilities. Many energy companies and utilities are present in the list of the largest European companies by revenue [73]. The top twenty European power industries produced $€ 628$ billion in 2015 [74].

The energy market income can be spread between companies, local utilities, SMEs and also citizens, thanks to the ongoing energy market liberalization and decentralisation process, in which the sharing of the economic benefits is the most interesting aspect. In the institutional decentralization process of energy, there is a strong rise of initiatives and projects, carried on by private and local communities' actions with a bottom-up approach.

The most interesting ones are related to the creation of widespread and sharing enterprises (small collective companies or local cooperatives) where citizens are directly involved and called Local Energy Communities (LECs) or Energy sustainable communities or, more generally, community cooperatives or green communities (extensive literature and debate on the subject exists [12,13,75-78].

The energy communities can be classified according to the following scheme (Figure 2). The main interest is the local link and the opportunity of being influenced by urban and spatial planning.

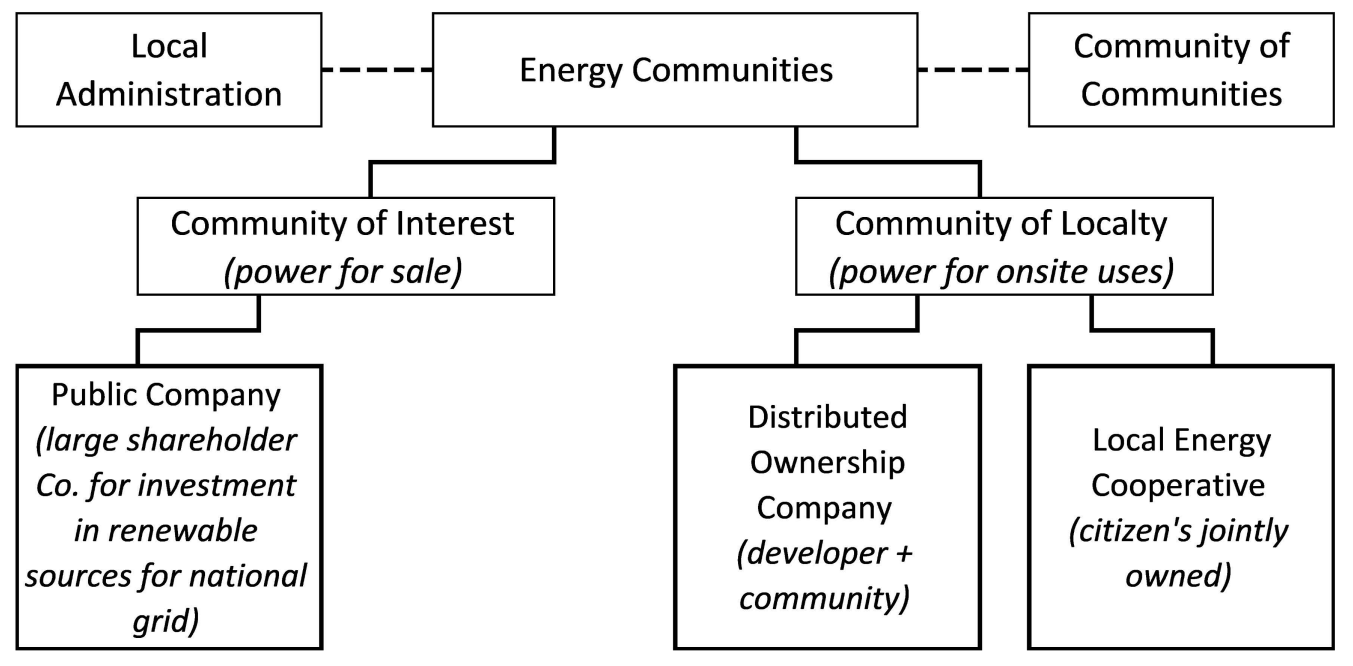

Figure 2. Typology of Energy Communities.

In many cases, energy communities are born under the promotion, support and involving of local authorities which play an important role in the integration of the socio-economic components within an institutional framework. An important role can also be played by citizens associations or citizens aggregations (Community of Communities), which provide economic investments and support for 
the service quality. There are different types of organizations, as shown in Figure 2, which represent a different level of linking with the territory and citizens engagement.

Unlike traditional energy utilities with a centralised ownership business model, Communities of Interest are generally big/medium companies (a kind of Public Companies) that invest in energy production plants based on renewable sources (wind, biogas, biomass, photovoltaic, hydroelectric) for selling the energy production through energy grids. Investors (public or private) have two main interests: (1) an ideological-cultural interest in supporting the environmental protection by replacing fossil fuels with renewable energy resources; and (2) an economic interest, addressed by income generated by energy production (power for sale) and energy services selling. In this case, it works like an investment fund, where the link with the territory is weak or non-existent.

Communities of Locality are instead promoted in many cases by local stakeholders (or in some cases under the initial support of external actors), aimed to install and manage local energy plants and infrastructure. Communities of Locality are also driven by a third interest related to the will of increasing the inclusive governance in the local development processes.

The business model of the Distributed Ownership Company is based on a developer who shares ownership within the local community, primarily with the landowners and landlords. The initiative can also start from a public offer open to all citizens.

Within the Community of Locality models, are relevant the Local Energy Communities (LECs), which can match locally the production and consumption of energy (onsite power) with several benefits, especially under the energy efficiency point of view. They share the property of energy plants and grids between all the inhabitants (jointly owned), with a cooperative governance business model (one man one vote). Local Energy Communities have a strong link with the territory and the local socio-cultural context.

In LEC the energy production and consumption become factors of social aggregation for local development, increasing the environment protection and valorisation as well as economic income, coming from the energy market. The energetic localism can be, as well, a driver for Strategic Urban Planning and an input for urban regeneration projects with a social inclusion aim [77].

In Europe, there are several initiatives and examples that work in the field of energy localism. The Danish experience, began in the 1970s, continues to be a worldwide reference for widespread decentralization based on a cooperative basis. This cooperative system covers $60 \%$ of the national energy needs [79].

More recently, the Britain experience, supported by the central government, built up a participatory system which is a direct expression and implementation force for the local planning strategies [80].

Experiences are underway in Germany, Sweden, Netherlands, and in other European countries, including transnational cooperation networks [13]. The EEA Report No 3/2017, Renewable energy in Europe [11] (p. 13) shows that "the European Federation of Renewable Energy Cooperatives represents 1.240 initiatives and 650,000 citizens. Its members have jointly invested $€ 2$ billion in installations to produce renewable energy. These installations have a production capacity of $1 \mathrm{GW}$. The combined annual turnover is as high as $€ 950$ million, and the cooperatives provide sustainable jobs for a considerable number of European citizens". This corresponds to an average for a single initiative of $€$ 1.6 million of investment, $€ 800,000$ of turnover, $0.8 \mathrm{MW}$ of production capacity.

There are international organizations which promote energy localism and the districts energy creation, such as the United Nations Environment Programme (UNEP) with the program "District Energy in Cities" [81] and the International Energy Agency (IEA) with the research program "International Hub for District Energy Research" [82].

In literature there are two main interpretations: (1) The District Energy and (2) The Energy District.

(1) The District energy focuses on defining/designing the energy systems more appropriate for the decentralization process, and the integration between production and supply to reduce the carbon intensity, to improve energy efficiency, to use the renewable and local resource, to develop 
a green economy and urban governance $[15,81,82]$. It focuses more on energy technologies and innovation in a defined urban area.

(2) The Energy District [83] instead mainly concerns the physical spatial (and social) context in which the energy innovation system is applied and contribute to the transformations of the urban organization.

UNEP [15] defines the first one as the main technological solution for the integration between different local energy supply sources and between these and users:

- connecting renewable electricity generation

- connecting commercial demand

- connecting industrial demand

- solar thermal connected to district heating

- capturing waste heat from sewage and wastewater

- waste incineration

- connecting sources of "free cooling"

- connecting residential customers

- combined heat and power (CHP) plant

- absorption chiller capturing waste heat

These technology options can be the basis to define District energy. The Energy District instead can be assumed as a territorial projection of the LEC. It represents the spatial context in which the LEC works, where is possible to match the energy demand and supply and where the inclusion business model can be developed. The Energy District, or better the Eco-Energy District, is configured as an economic collective enterprise for the production, self-consumption and selling of energy and related services. It works also as a booster for other local economic activities related with energy, such as waste to energy, waste recycling, biomass, water cycle, agri-food production, handicraft production and small industry, and so on.

An interesting definition of the Energy District comes from the FED (Fossil Free Energy Districts) [83] project tested in Gothenburg and developed within the European Initiative UIA (Urban Innovative Actions). The FED project is based on a novel district energy system, integrating electric power, as well as heating and cooling, generated from renewable sources, having as a main focus the balancing of the demand. The introduction of renewable sources "optimizes different buildings usage profiles: one building's energy needs will be balanced with the surplus of another. Intermediate storage, fundamental to be a success, consists of heating/cooling storage in the building's structure, accumulation tanks or geothermal heat pumps, and batteries for electricity. An ICT service will support future volatile energy markets."

The Energy District is therefore based on the mutual exchange of energy coming from different productions and from different storage sets between different stakeholders, in relation to the variations in the energy demand.

The optimization of this dynamic system, also in terms of design, leads to the creation of the Energy District and can contribute the increasing of the democratic process and sharing community.

The process of liberalization and privatization of the energy market does not open this economic sector only to large investors, but also to large numbers of "prosumers" (producers and consumers), and local communities with inclusive and shared governance. In this way, the Energy District be a socio-spatial project in which converge the eco-energy innovation, the territorial transformation, the shared socio-economic development, and inclusive governance.

The project of the Energy District (or Eco-Energy) becomes a vehicle for implementing the Urban Master Plan, with an energy-oriented aim, or a specific action of the SEAP according to the Urban Master Plan. Thus, the Urban Master Plan assumes a systemic relevance and not only a regulatory aim for the building sector, in order to achieve the energy transition. 
The local Eco-Energy District follows the eco-districts movement (see above) but adding two new elements: first, the economic value coming from the outset of collective and inclusive enterprises, and second the creation of open microgrid connected with the existing ones and suitable for the development of an urban system as a network of networks. The energy localism proposes interesting prospects for the integration of energy in the strategic and spatial planning, showing opportunities for social inclusion, collective development, shared governance, and for urban regeneration, in line with the concept of sharing sustainability [84].

\section{Conclusions}

Since the 1970s, researchers have studied the direct relationship between physical urban characteristics and energy systems. The relationship between energy and physical-functional organization has outlined the relevance of including energy-related planning and strategies in the spatial planning. The ongoing tendency to separate Energy topic from the Spatial Planning increases the numbers of energy strategies, policies and actions, making them unintegrated, with less impact on the city and less efficient results in the long term. This lack of integration decreases the capacity to develop zero-carbon, or low-carbon, cities and societies, due to the complexity to manage the two-way relationships. The different experiences have shown a preference in implementing policies and actions with limited and short time return achievements, and with less structural impacts. The expansion of environmental and energy goals, and the recent needs for structural actions in urban management may lead to a better consideration of the strategic role adopted by Spatial Planning. In this framework, the energy topic will become a crucial driver in all urban decisions and interventions, especially those which are related to Urban transformation and regeneration. It is important to re-think the role of the Spatial and Urban Planning as a strategic tool, due to its power and influence on land use, private property rights, mobility, infrastructures, urban design, urban comfort, etc. Some good practices in the path towards a better integration among energy, economy, sustainability, inclusion, mobility etc. are now gaining importance in different nations. These practices focus on developing Decentralised Energy System, Local Energy Communities, and Energy Districts. The bottom-up strategies and actions are crucial for shifting the current Urban Planning paradigm. The holistic and strategic Spatial Plan must promote these bottom-up initiatives by providing the regulatory base for their implementation. This is the right path to follow, as it has already been proven successful in many communities and sectors, also unexpected: “... when the world-spread governmental power cannot assume responsibilities, local actions can make the difference ..." [85].

Author Contributions: Conceptualization, P.D.P. and A.B.; Methodology, P.D.P and A.B.; Validation, P.D.P. and A.B.; Formal Analysis, P.D.P. and A.B.; Resources, P.D.P. and A.B.; Data Curation, A.B.; Writing-Original Draft Preparation, A.B.; Writing-Review \& Editing, A.B.; Supervision, P.D.P.; Project Administration, P.D.P.; Funding Acquisition, P.D.P.

Funding: This research received no specific grant from any funding agency in the public, commercial, or not-for-profit sectors.

Conflicts of Interest: The authors declare no conflict of interest.

\section{References}

1. Altshuler, A. Review of the Costs of Sprawl. J. Am. Inst. Plan. 1977, 43, 202-209.

2. Breheny, M. The compact city and transport energy consumption. Trans. Inst. Br. Geogr. 1995, 20, 81-101. [CrossRef]

3. Knowles, R. Energy and Form: An Ecological Approach to Urban Growth; MIT Press: Cambridge, MA, USA, 1974; ISBN 0262610256.

4. Givoni, B. Climate Considerations in Building and Urban Design; John Wiley \& Son: New York, NY, USA, 1998; ISBN 978-0-471-29177-0.

5. Owens, S. Energy, Planning and Urban Form; Pion Limited: London, UK, 1986; ISBN 0850861187.

6. Owens, S.E. Land-Use Planning for Energy Efficiency. Appl. Energy 1992, 43, 81-114. [CrossRef] 
7. Ratti, C.; Baker, N.; Steemers, K. Energy Consumption and Urban Texture. Energy Build. 2005, 37, 762-776. [CrossRef]

8. European Commission. Urban Agenda for the EU; Amsterdam, NL, 2016. Available online: http:/ / ec.europa.eu/regional_policy/sources/policy/themes/urban-development/agenda/pactof-amsterdam.pdf\%0Ahttp:/ / urbanagendaforthe.eu/ (accessed on 17 October 2018).

9. Meijers, E.; Romein, A.; Stead, D.; Grot, N.B.; Fertner, C.; Große, J. Thematic Report on Urban Energy Planning: Buildings, Industry, Transport and Energy Generation. The PLEEC Project; 2015. Available online: http:/ /www. pleecproject.eu/ (accessed on 17 October 2018).

10. Dóci, G.; Vasileiadou, E.; Petersen, A.C. Exploring the Transition Potential of Renewable Energy Communities. Futures 2015, 66, 85-95. [CrossRef]

11. European Environmental Agency. Renewable Energy in Europe. Recent Growth and Knock-on Effects; Publications Office of the European Union: Luxembourg, 2016; ISBN 978-92-9213-848-6. Available online: http:/ / www. eea.europa.eu/publications / renewable-energy-in-europe-2016 (accessed on 17 October 2018).

12. Koirala, B.P.; Koliou, E.; Friege, J.; Hakvoort, R.A.; Herder, P.M. Energetic Communities for Community Energy: A Review of Key Issues and Trends Shaping Integrated Community Energy Systems. Renew. Sustain. Energy Rev. 2016, 56, 722-744. [CrossRef]

13. REScoop. What Local Energy Communities Need from the Clean Energy Package; 2017. Available online: http:/ / www.eea.europa.eu/publications/renewable-energy-in-europe-2016 (accessed on 17 October 2018).

14. King, M. Community Energy: Planning, Development and Delivery; International District Energy Association: London, UK, 2012; Volume 1.

15. UNEP. District Energy: Unlocking the Potential of Energy Efficiency and Renewable Energy; United Nations Environment Programme: Paris, France, 2015; Available online: http:/ / www.unep.org/energy/portals / 50177/DES_District_Energy_Report_full_02_d.pdf (accessed on 17 October 2018).

16. Zanon, B.; Verones, S. Climate Change, Urban Energy and Planning Practices: Italian Experiences of Innovation in Land Management Tools. Land Use Policy 2013, 32, 343-355. [CrossRef]

17. Kona, A.; Melica, G.; Bertoldi, P.; Rivas, S.; Koffi, B.; Iancu, A.; Zancanella, P.; Janssens-Maenhout, G.; Dallemand, J. Covenant of Mayors in Figures: 8-Year Assessment; Joint Research Centre: Luxembourg, 2017.

18. Christoforidis, G.C.; Chatzisavvas, K.C.; Lazarou, S.; Parisses, C. Covenant of Mayors Initiative-Public Perception Issues and Barriers in Greece. Energy Policy 2013, 60, 643-655. [CrossRef]

19. Rivas, S.; Melica, G.; Kona, A.; Serrenho, T.; Iancu, A.; Koffi, B.; Gabrielaitiene, I.; Bertoldi, P. The Covenant of Mayors: In-Depth Analysis of Sustainable Energy Actions Plans; Publication Office of the European Union: Luxembourg, 2015.

20. Kona, A.; Melica, G.; Rivas Calvete, S.; Zancanella, P.; Iancu, A.; Gabrielaitiene, I.; Saheb, Y.; Janssens-Manhout, G.; Bertoldi, P. The Covenant of Mayors in Figures and Performance Indicators: 6-year Assessment; JRC 57789; Publications Office of the European Union: Luxembourg, 2015.

21. Croci, E.; Lucchitta, B.; Janssens-Maenhout, G.; Martelli, S.; Molteni, T. Urban $\mathrm{CO}_{2} \mathrm{Mitigation} \mathrm{Strategies}$ under the Covenant of Mayors: An Assessment of 124 European Cities. J. Clean. Prod. 2017, 169, 161-177. [CrossRef]

22. Cajot, S.; Peter, M.; Bahu, J.M.; Guignet, F.; Koch, A.; Maréchal, F. Obstacles in Energy Planning at the Urban Scale. Sustain. Cities Soc. 2017, 30, 223-236. [CrossRef]

23. Stoeglehner, G.; Neugebauer, G.; Erker, S.; Narodoslawsky, M. Integrated Spatial and Energy Planning: Supporting Climate Protection and the Energy Turn with Means of Spatial Planning; Springer Nature: Berlin, Germany, 2016; ISBN 3319318705.

24. Große, J.; Fertner, C.; Groth, N.B. Urban Structure, Energy and Planning: Findings from Three Cities in Sweden, Finland and Estonia. Urban Plan. 2016, 1, 24. [CrossRef]

25. Real Estate Research Corporation. The Costs of Sprawl: Environmental and Economic Costs of Alternative Residential Development Patterns at the Urban Fringe; U.S. Government Printing Office: Washington, DC, USA, 1974.

26. Scott, M. American City Planning Since 1890; University of California Press: Berkeley, CA, USA, 1969; ISBN 1884829090.

27. Burchell, R.W.; Listokin, D. Energy and Land Use; Rutgers-the State University: Brunswick, NJ, USA, 1982.

28. Windsor, D. A Critique of the Costs of Sprawl. J. Am. Plan. Assoc. 1979, 45, 279-292. [CrossRef] 
29. Bruegmann, R. Sprawl: A Compact History; The University of Chicago Press: Chicago, IL, USA, 2005; ISBN 0226076911.

30. Breheny, M. Rejoinder A. Trans. Inst. Br. Geogr. 1995, 20, 384-386. [CrossRef]

31. Raydan, D.; Steemers, K. Environmental Urban Design. In Environmental Design of Urban Buildings; Santamouris, M., Ed.; Earthscan: London, UK, 2006; ISBN 1902916425.

32. Olgyay, V. Design with Climate; Princeton University Press: Princeton, NJ, USA, 1963; ISBN 9781400873685.

33. McHarg, I. Design with Nature; Natural History Press: New York, NY, USA, 1969; ISBN 047111460X.

34. Martin, L.; March, L. Urban Space and Structures; Cambridge University Press: London, UK, 1972; ISBN 9780521099349.

35. Oke, T.R. Canyon geometry and nocturnal urban heat island: Comparison of scale model and field observations. J. Clim. 1981, 1, 237-254. [CrossRef]

36. Oke, T.R. Parametrization of heat storage in urban areas. Urban Ecol. 1981, 5, 45-54. [CrossRef]

37. EU Project UHI. Development and Application of Mitigation and Adaptation Strategies and Measures for Counteracting the Global Urban Heat Island Phenomenon. Available online: http:/ / eu-uhi.eu/it/ (accessed on 17 October 2018).

38. Rosenfeld, A.H.; Akbarib, H.; Romma, J.J.; Pomerantz, M. Cool communities: Strategies for heat island mitigation and smog reduction. Energy Build. 1998, 28, 51-62. [CrossRef]

39. REG-VALOREN Program. Available online: http://www.cordis.europa.eu/programme/rcn/131_en.html (accessed on 17 October 2018).

40. Newman, P.; Kenworthy, J. Cities and Automobile Dependence: An International Sourcebook; Gower Publishing: Aldershot, UK, 1989; ISBN 0566070405.

41. Newman, P.; Kenworthy, J. Sustainability and Cities: Overcoming Automobile Dependence; Island Press: Washington, DC, USA, 1999; ISBN 1559636602.

42. Newman, P.; Kenworthy, J. The End of Automobile Dependence; Island Press: Washington, DC, USA, 2015; ISBN 1610914635.

43. Legge 10/91. Available online: http://www.fire-italia.org/prova/wp-content/uploads/2015/04/ termotecnica1.pdf (accessed on 15 January 2018).

44. CNR. 1983-1989 Relazione Finale Sull'attività Svolta e Sui Risultati Conseguiti; PFE: Rome, Italy, 1990.

45. Verones, S.; Zanon, B. Energia e Pianificazione Urbanistica, Verso una Integrazione Delle Politiche Urbane; FrancoAngeli: Milan, Italy, 2012; pp. 20-45, ISBN 8820417316.

46. ISTAT Energia. Available online: http:/ / dati.istat.it (accessed on 15 January 2018).

47. PEC 2007. Available online: http://www.comune.bologna.it/documenti/ambiente/energia/atlante.pdf (accessed on 17 October 2018).

48. PRODEM Provincia di Modena 2006. Available online: http://www.provincia.modena.it/page.asp? IDCategoria $=7 \&$ IDSezione $=863 \& I D=70797$ (accessed on 17 October 2018).

49. Piano Territoriale di Coordinamento Provinciale 2009. Available online: http://www.territorio.provincia. modena.it / page.asp?IDCategoria=121\&IDSezione=3930 (accessed on 17 October 2018).

50. Bertoldi, P.; Cayuela, D.B.; Monni, S.; De Raveschoot, R.P. How to Develop a Sustainable Energy Action Plan (SEAP); JRC 57789; Publications Office of the European Union: Luxembourg, 2010.

51. Pablo-Romero, M.d.P.; Pozo-Barajas, R.; Sánchez-Braza, A. Analyzing the Effects of Energy Action Plans on Electricity Consumption in Covenant of Mayors Signatory Municipalities in Andalusia. Energy Policy 2016, 99, 12-26. [CrossRef]

52. COP21: EU Institutions Strengthen Alliance with Cities through New Covenant of Mayors for Climate and Energy. Available online: http:/ / cor.europa.eu/it/news/Pages/COP21-New-Covenant-of-Mayors.aspx (accessed on 17 October 2018).

53. Delponte, I.; Pittaluga, I.; Schenone, C. Monitoring and Evaluation of Sustainable Energy Action Plan: Practice and Perspective. Energy Policy 2017, 100, 9-17. [CrossRef]

54. Bulkeley, H.; Castan Broto, V. Government by Experiment? Global Cities and the Governing of Climate Change. Trans. Inst. Br. Geogr. 2013, 38, 361-375. [CrossRef]

55. Dall'O', G.; Norese, M.F.; Galante, A.; Novello, C. A Multi-Criteria Methodology to Support Public Administration Decision Making Concerning Sustainable Energy Action Plans. Energies 2013, 6, 4308-4330. [CrossRef] 
56. Bulkeley, H.; Andonova, L.; Bäckstrand, K.; Betsill, M.; Compagnon, D.; Duffy, R.; Kolk, A.; Hoffmann, M.; Levy, D.; Newell, P.; et al. Governing Climate Change Transnationally: Assessing the Evidence from a Database of Sixty Initiatives. Environ. Plan. C Gov. Policy 2012, 30, 591-612. [CrossRef]

57. Biesbroek, G.R.; Swart, R.J.; van der Knaap, W.G.M. The Mitigation-Adaptation Dichotomy and the Role of Spatial Planning. Habitat Int. 2009, 33, 230-237. [CrossRef]

58. IPCC. Climate Change 2007: Impacts, Adaptation and Vulnerability: Contribution of Working Group II to the Fourth Assessment Report of the Intergovernmental Panel; IPCC: Geneva, Switzerland, 2007.

59. Musco, F. I piani clima, nuovi strumenti per la pianificazione locale: Dalla mitigazione all'adattamento. In Energia e Pianificazione Urbanistica, Verso una Integrazione Delle Politiche Urbane; Verones, S., Zonon, B., Eds.; FrancoAngeli: Milan, Italy, 2012; pp. 20-45, ISBN 8820417316.

60. Camagni, R. Nuovi obiettivi e nuovi paradigmi per la pianificazione territoriale. In La Città di Domani; Franz, G., Ed.; Facoltà di Architettura di Ferrara e Regione Emilia-Romagna: Ferrara, Italy, 2000; pp. 21-29.

61. Dobbelsteen, A.V.D.; Jansen, S.; Timmeren, A.V.; Roggema, R. Energy Potential Mapping-A Systematic Approach to Sustainable Regional Planning Based on Climate Change, Local Potentials and Exergy. In Proceedings of the CIP World Building Conference, Cape Town, South Africa, 14-15 May 2007.

62. Stremke, S.; Dobbelsteen, A.V.D. Sustainable Energy Landscapes. Designing, Planning, and Development; Taylor\&Francis: Copenagen, Denmark, 2013; ISBN 9781439894385.

63. Stratego Project. Available online: www.stratego-project.eu (accessed on 17 October 2018).

64. Perry, C. The Neighborhood Unit. From the Regional Plan of N. Y. and Its Environs; Routledge/Thoemmes Press: Oxford, UK, 1929; ISBN 0415160855. Available online: http:/ / www.sethspielman.org/courses/geog3612/ readings/Perry.PDF (accessed on 17 October 2018).

65. Le Corbusier. L'Unité d'Habitation de Grandeur Conforme. Available online: http://www. fondationlecorbusier.fr / corbuweb / morpheus.aspx?sysId=13\&IrisObjectId=5234\&sysLanguage=frfr\&itemPos=58\&itemSort=fr-fr_sort_string1\%20\&itemCount=78\&sysParentName=\&sysParentId=6 (accessed on 17 October 2018).

66. Loerakker, L.O.J. Revisioning Amsterdam Bijlmermeer. Available online: https://www.failedarchitecture. com/the-story-behind-the-failure-revisioning-amsterdam-bijlmermeer/ (accessed on 17 October 2018).

67. Verlaan, T. Life inside Le Vele di Scampia. Available online: https://www.failedarchitecture.com/fabookmarks /life-inside-the-vele-di-scampia / (accessed on 17 October 2018).

68. Ministère du Logement et de 1'Habitat Durable. Impulser une Nouvelle Ambition Pour les EcoQuartiers. Available online: http:/ / www.logement.gouv.fr/les-ecoquartiers (accessed on 17 October 2018).

69. Codecasa, G.; Antoniacomi, G. Ripensare l'agenda pubblica. Retorica ed evoluzione dell'azione amministrativa. In Energia e Pianificazione Urbanistica, Verso una Integrazione Delle Politiche Urbane; Verones, S., Zonon, B., Eds.; FrancoAngeli: Milan, Italy, 2012; pp. 50-62, ISBN 8820417316.

70. EUROSTAT. Energy Intensity of the Economy. 2016. Available online: http://ec.europa.eu/eurostat/tgm/ table.do?tab=table\&init=1\&language $=$ en\&pcode $=$ tsdec360\&plugin=1 (accessed on 17 October 2018).

71. EU Reference Scenario. Energy, Transport and GHG Emissions. Trends to 2050. 2016. Available online: http:/ / pure.iiasa.ac.at/id/eprint/13656/3/20160712_Summary_Ref_scenario_MAIN_RESULTS\% 20\%282\%29-web.pdf (accessed on 17 October 2018).

72. EUROSTAT GDP at Current Market Price 2016. Available online: http:/ / ec.europa.eu/eurostat/statisticsexplained/index.php/File:GDP_at_current_market_prices,_2006_and_2014-2016_YB17.png (accessed on 17 October 2018).

73. Wikipedia. Available online: https://en.wikipedia.org/wiki/List_of_largest_European_companies_by_ revenue (accessed on 17 October 2018).

74. Prospex Research. Europe's Top Twenty Power Industry Players 2016; Prospex Research Ltd.: Brighton, UK, 2016; Available online: http://www.prospex.co.uk/LiteratureRetrieve.aspx?ID=140423 (accessed on 17 October 2018).

75. van der Schoor, T.; Scholtens, B. Power to the people: Local community initiatives and the transition to sustainable Energy. Renew. Sustain. Energy Rev. 2015, 43, 666-675. [CrossRef]

76. Public Affairs Bruxelles, What Role for 'Local Energy Communities' in the EU Energy Transition? Available online: https: / www.pubaffairsbruxelles.eu/ event-highlights-what-role-for-local-energy-communitiesin-the-eu-energy-transition/ (accessed on 17 October 2018).

77. De Pascali, P. Città ed Energia; FrancoAngeli: Milan, Italy, 2008; ISBN 9788846499288. 
78. De Pascali, P. Evidenze territoriali dell'energia e modelli di localismo energetico per il piano. In L'energia Nelle Trasformazioni del Territorio; De Pascali, P., Ed.; FrancoAngeli: Milan, Italy, 2014; ISBN 9788891711250.

79. DTI. Co-Operative Energy: Lessons from Denmark and Sweden. Available online: http://www.uk.coop/ sites/storage/public/downloads/36247mr_0_0.pdf (accessed on 17 October 2018).

80. DECC. Community Energy: Call of Evidence. Available online: https://www.gov.uk/government/ consultations / community-energy-call-for-evidence (accessed on 17 October 2018).

81. United Nations Environment Programme (UNEP). District Energy in Cities Initiative. Available online: https: / / staging.unep.org/energy/districtenergyincities (accessed on 17 October 2018).

82. IEA. District Heating and Cooling and Combined Heating and Power. Available online: http://www.ieadhc.org/home.html (accessed on 17 October 2018).

83. FED Fossil Free Energy Districts. Available online: https://www.uia-initiative.eu/en/uia-cities/gothenburg (accessed on 17 October 2018).

84. De Pascali, P.; Reginaldi, M. Inclusive energy as model of sharing sustainability for planning. CRIOS 2016, 12, 41-54. [CrossRef]

85. Pope Francesco, Encyclical Letter. Laudato Si'. 2015. Available online: http://w2.vatican.va/content/ francesco/it/encyclicals/documents / papa-francesco_20150524_enciclica-laudato-si.html (accessed on 17 December 2018).

(C) 2018 by the authors. Licensee MDPI, Basel, Switzerland. This article is an open access article distributed under the terms and conditions of the Creative Commons Attribution (CC BY) license (http://creativecommons.org/licenses/by/4.0/). 